\title{
Mis/quotation in Constrained Writing
}

\author{
Peter Kirwan
}

So now I come to speak. At last. I will tell you all I know. I was deceived to think I could not do this. I have the powers; I take them here. I have the right. I have the means. My words may be poor, but they will have to do. ${ }^{1}$

I begin with a quotation about words, a quotation that is itself an amalgamation of other quotations; it is made up entirely of words spoken by Ophelia in Hamlet. It is a statement of the ability and right to speak, a re-appropriation of words already spoken in order to say something new - or something old that needs to be heard in a new way. Yet this quotation also admits the limitations of the speaker's 'poor' words, words that 'will have to do'. This chapter's concern is the creative negotiation of the restrictions implicit in quotation, the extents to which free expression is curtailed or enabled by the use of another's words. As the speaker of the above extract articulates her own self-awareness and agency, she also expresses metafictional cognisance of her limited vocabulary; a limitation that this chapter argues is endemic to the very act of quotation. ${ }^{2}$

Quotation is, at its core, an act of creative appropriation. This might initially seem counterintuitive; the introduction into a new work of a pre-existing source might be read as a restriction of potential meaning, stymieing originality by defaulting to another's words. But a quotation's meaning is not intrinsic or fixed but dependent entirely on the strategic re-situation of words in each new context; while the quoted words may be presented as having authority, this authority is shaped by the one deploying it in service of a new agenda. In this view, the creative act is not the writing of new words, but the skilful arrangement of pre-existing words to a new purpose. The texts I discuss here take this to an extreme in quoting strategies which, rather than deploy discrete Shakespearean soundbites, instead draw their entire vocabulary from limited Shakespearean corpora. Ben Power's play A Tender Thing (2009) reorganises the text of Romeo and Juliet to tell the story of an elderly couple dealing with their mortality, while Paul Griffiths' Oulipian novel let me tell you (2008) narrows its focus further to create an imaginative prequel to Hamlet using only words spoken in the play by Ophelia. Both texts deploy the confinement articulated in Margreta de Grazia's reading of Barthes:

Affixing a quotation to a speaker is motivated by the same impulse as affiliating a work to an author: both work to limit the generativity of language, confining it to the perimeters of a single consciousness (and its complementary unconscious), ordinary or extraordinary. ${ }^{3}$

\footnotetext{
${ }^{1}$ Paul Griffiths, let me tell you (Hastings: Reality St. Editions, 2008), p. 8. Subsequent references are given in parentheses in the text.

${ }^{2}$ See also chapter 4 in this collection.

${ }^{3}$ Margreta de Grazia, 'Shakespeare in Quotation Marks' in Jean I. Marsden (ed.), The Appropriation of Shakespeare: Post-Renaissance Reconstructions of the Works and the Myth (New York: Harvester Wheatsheaf, 1991), pp. 57-71 (p. 68).
} 
While the two works are both new, they confine themselves to the perimeters of a single consciousness - Shakespeare's - by restricting themselves to his words. If Shakespearean quotations carry authority, then that authority theoretically underpins every word.

Both texts adhere (with different degrees of rigidity) to self-imposed rules that seek liberation through confinement, exploiting the creative tension offered by a limited vocabulary and the 'ghosting' presence of two Shakespearean ur-texts that are among Shakespeare's most widely disseminated and adapted plays. ${ }^{4}$ Romeo and Juliet and Hamlet exert powerful interpretive force on texts that appropriate their stories, characters and words, yet these histories of appropriation allow Power and Griffiths to enter a space of confinement which nonetheless is semantically and culturally rich in proliferating meanings. Both texts are influenced by the Oulipian school, described thus by Daniel Becker:

Since its creation in $1960 \ldots$ oulipian inquiry has yielded novels without certain vowels, love stories without gender, poems without words, books that never end, books that do nothing but end, books that would technically take longer to read than most geological eras have lasted ... These works, all of them governed in some way by strict technical constraints or elaborate architectural designs, are attempts to prove the hypothesis that the most arbitrary structural mandates can be the most creatively liberating. ${ }^{5}$

Part of the pleasure of reading oulipian literature is becoming conscious of the authorial ingenuity required in adhering to the work's rules of creation. These rules allowboth authors simultaneously to subordinate themselves to Shakespeare (both texts proclaim on their back covers their deference to Shakespeare's words) and to foreground more subtly their own agency in redistributing Shakespeare's words to new purpose. The reader or audience familiar with Romeo and Juliet and Hamlet should, theoretically, be able to recognise every word as Shakespearean, and yet the works are rather misquotations on a massive scale, juxtaposing Shakespearean words and lines in unfamiliar ways. As such, the texts demand a more active, even creative, form of participation and recognition from their audiences.

\section{A Tender Thing}

The RSC production of Ben Power's A Tender Thing premiered in Newcastle-upon-Tyne in 2009 and was revived in 2012 in Stratford-upon-Avon as the closing production of the World Shakespeare Festival. The play is a two-hander, with an intimate, domestic focus following an elderly couple reflecting on their life together while their health deteriorates. Most of Romeo and Juliet is discarded in favour of those lines that best fit this narrative. The following, from the opening scene, is indicative of Power's adaptive strategies. Romeo enters carrying a small bottle while Juliet sleeps in bed. Following a long opening speech that draws from Romeo's final lines in Romeo and Juliet 5.3, Juliet awakes and the two engage in the following dialogue (I mark the original speaker and corresponding line reference in the right hand column):

JULIET: Good even to my ghostly confessor.

Juliet (2.6.21)

Either my eyesight fails or thou lookst pale.

Juliet (3.5.57)

\footnotetext{
${ }^{4}$ On 'ghosting', see Marvin Carlson, The Haunted Stage (University of Michigan Press, 2001).

${ }^{5}$ Daniel Levin Becker, Any Subtle Channels: In Praise of Potential Literature (Cambridge MA: Harvard University Press, 2012), p. 6.
} 
ROMEO: And trust me, love, in my eye so do you.

Romeo (3.5.58)

Is there no pity sitting in the clouds

Juliet (3.5.196-7)

That sees into the bottom of our grief?

Eyes, look your last. Arms, take your last embrace. Romeo (5.3.112-3)

And lips ...

JULIET: Sssh.

(original)

I do remember well where we should be

Juliet (5.3.149-50)

And here we are. Where is my Romeo?

ROMEO: Call me but love and I'll be new baptis'd:

Romeo (2.2.50-1)

Henceforth I'll never be thy Romeo.

JULIET: Did my heart love till now? Forswear it, sight. Romeo (1.5.51-2)

For I ne'er saw true beauty till this night.

Give me thy hand. ${ }^{6}$

Friar Laurence (3.3.172);

Romeo (5.3.81); Capulet (5.3.296)

In performance the audience hears a sequence of recognisable lines, most of which are spoken in Romeo and Juliet by the correlating characters. Yet Power's text rearranges the play and reverses the arc of Shakespeare's. The tomb-like setting of the bed that will become their deathbed is introduced with words taken from Romeo's dying speech (5.3), but then the dialogue moves backwards through their parting (3.5), then their first declarations of love (2.2), then first sight (1.5). The effect is twofold. First, this is a microcosm for the narrative circularity of Power's story, which inverts the trajectory of Romeo and Juliet by bringing the couple ever closer together rather than parting them. The play's epilogue evokes an afterlife in which the couple, 'suddenly younger than we have known them', appear to each other as strangers and play through the entire first-sight sequence of 1.5; love and death never part Power's characters (38). More poignantly, Power's choice to begin at the end implies the characters are regressing throughout, imagining mental decline as second childhood.

The play invites its audience to recall and rewrite Romeo and Juliet, playing tricks with collective memory by destabilising the familiar and substituting new memories through the distorted life history of Power's characters. Speaking of experiencing citation in performance, Margaret Jane Kidnie writes:

Citation occupies a strange space in performance. It belongs to the event, yet seems to arrive from somewhere else, bringing with it another's voice and authority. This

\footnotetext{
${ }^{6}$ Ben Power, A Tender Thing (London: Nick Hern, 2009), p. 8. Subsequent references are given in parentheses in the text.
} 
inherent intertextual condition creates as an effect of language the certainty that quotation, here seemingly out of place, has an identifiable origin. ${ }^{7}$

The reorganisation and redistribution of lines in A Tender Thing insisted on the play's separateness from Romeo and Juliet, depending on the audience's recognition of famous lines dislocated from their original context. Characters are not restricted only to the lines of their corresponding Shakespearean character; perhaps most notably, Juliet speaks the Queen Mab speech while teasing Romeo immediately before her first collapse. While Power's characters operate as coherent dramatic entities, they are also fractured through the audience's own active process of recognition, the pleasure of memory that Anne Ubersfeld identifies as a key pleasure of the theatre: 'The superimposing of the preceding element on the new one makes a new construction possible, and, there again, the spectator tests how alert his [sic] intelligence is in the utilization of an agile memory. ${ }^{8}$ Power's characters both are and are not Romeo and Juliet, at once both textual deconstructions of Shakespearean figures and an elderly couple approaching death.

The agility noted by Ubersfeld is key to a play that repeatedly reminds its audience to remember while staging the traumatic loss of memory in advanced old age. The audience partakes in the attempt to latch on to the 'certainty' of textual origin that Kidnie identifies. In the theatre this can be a distressing experience, mirroring the sense of uncanny dislocation that the ailing and forgetful Juliet experiences. In one of her scenes of confusion, Juliet 'pulls away from' Romeo and cries out:

Oh, where's my daughter? I did bid her come,

And now she is with God.

On Lammas Eve at night then was she born.

That was she, marry, I remember it well.

'Tis since the earthquake a great many years;

And she was wean'd - I never shall forget it -

Of all the days of the year, upon that day. (30)

As Juliet casts about into her fading memory, recalling her lost daughter as a presence, then an absence, Power uses an extended evocation of memory to illustrate precisely what is at danger of being forgotten. Power takes words spoken by the Nurse and Lady Capulet that might be overlooked in performance and foregrounds them in A Tender Thing as belonging to Juliet herself. The verbal dislocation emphasises the sense of loss; not only does the audience witness the pain of A Tender Thing's Juliet, but they may experience a moment of cognitive dissonance in imagining Juliet having a child at all. By aligning Lady Capulet, the Nurse and the two Juliets in this moment, Power turns Shakespeare's brief mention of a lost child into an emotional, polyvocal cry.

This dependence on the experience of recognition for dramatic effect cannot operate on all audience members in the same way. Lyn Gardner noted in her review, 'Familiarity with the

\footnotetext{
${ }^{7}$ Margaret Jane Kidnie, 'Citing Shakespeare’ in Peter Holland (ed.), Shakespeare, Memory and Performance (Cambridge University Press: 2006), pp. 117- 32 (p. 125).

${ }^{8}$ Anne Ubersfeld, 'The Pleasure of the Spectator', trans. Pierre Bouillaguet and Charles Jose, in Performance: Critical Concepts in Literary and Cultural Studies (London: Routledge, 2003), vol. II, pp. 236- 48 (p. 240).
} 
original will deepen this experience, even if it never escapes the feeling of being a clever workshop idea', while Dominic Cavendish felt that 'while the verse is intoxicating' it was 'shorn of dramatic context'. ${ }^{9}$ Cavendish's experience here contradicts Gardner's assumption. His reaction is based on the sense of a lack; Power's play of course has dramatic context, but the experienced reviewer is more attuned to the lack of the specific original dramatic context that, for him, makes sense of the lines. Gardner also contradicts herself - it is her familiarity with Shakespeare that makes this play seem like a workshop idea, whereas a less experienced audience may be freer to experience the emotional impact of Power's story. The process of recognition may then be a barrier to emotional experience; the play's strategies work best when, as in the evocation of Juliet's lost child above, the new narrative does not depend on recognition of the original for its impact.

Power's strategy becomes more manipulative when A Tender Thing invites its audience to remember what was never there, as in the central scene, in which Juliet insists that Romeo enable her suicide at the appropriate time:

\section{JULIET: Hear me.}

I shall not bear it, love, but choose to sleep,

Submitting to that timeless cold embrace,

And ending this unnatural decay.

'Tis better far to sleep, at peace, in love,

Than stretched upon this tortured rack of life.

If, in thy wisdom, thou canst give no help,

Nor no physician cure the sufferings to come,

If thou remember all our happiness past

And if thou loves me, as thou sayst thou dost,

Do thou then call my resolution wise,

And with our hands we'll help it presently. (24)

The final couplet, a paraphrase of Romeo 4.1.53-4, may be recognised as a quotation, and in turn serves to authenticate the preceding lines which are actually original to this play. One reviewer, while emphasising the play's use of 'Shakespearean words', even singled out the phrase 'end this unnatural decay' despite this being entirely original to Power. ${ }^{10}$ NotShakespeare becomes Shakespeare through the lack of marked differentiation, the 'invisible quotation marks around the Shakespearean language' that Kidnie identifies as necessary for the demarcation of citation in explicit confrontations with Shakespeare such as those of the Reduced Shakespeare Company. ${ }^{11}$ This is not the 'deferential relationship' of citation, nor the 'supportive or questioning' relationship of quotation described by Julie Sanders, but the subtle

\footnotetext{
${ }^{9}$ Lyn Gardner, 'A Tender Thing - Review', The Guardian, 4 October 2012; Dominic Cavendish, 'A Tender Thing, RSC Swan, Stratford-upon-Avon, review', The Telegraph, 8 October 2012.

${ }^{10}$ Natasha Tripney, 'A Tender Thing', The Stage, 4 October 2012, https://www.thestage.co.uk/reviews/2012/atender-thing-review-at-swan-stratford-upon-avon/ (last accessed 9 May 2017)

${ }^{11}$ Kidnie, 'Citing Shakespeare', p. 129.
} 
and potentially (mis)leading utilisation of the pseudo-Shakespearean. ${ }^{12}$ The overarching Shakespearean authority implicit in the text's rules of creation is ascribed to the new text; Power's breaking of the rules enables him, effectively, to co-opt Shakespeare's voice to authorise his own writing.

In playing with its audience's assumed memory - for the concept assumes familiarity with Romeo and Juliet - A Tender Thing demonstrates the inherent metatheatricality of the quotation device, inviting creative interpretive engagement with the $u r$-text on which it depends. Yet the amalgamation of pseudo-Shakespearean new writing with decontextualised Shakespeare lines also raises the ethical and intellectual question of how far an audience conditioned to recognise Shakespeare will go in constructing the new text as Shakespearean. The constraining superstructure of Shakespeare that governs the rules of the text is also a shorthand for audience accessibility that frees Power from the need to establish character, backstory and poetry. For Power, this freedom enables a creative exploration of issues surrounding aging, euthanasia and loss that can be judged and contextualised against a Shakespearean standard; the flipside, as Cavendish's comments reveal, is that knowledge of the Shakespearean context may detract from the purposes of the new text. This tension is exacerbated in the second of my texts, where more rigid restrictions of language align paradoxically with even greater independence from Shakespeare.

\section{let me tell you}

Paul Griffiths' short novel let me tell you is far stricter than A Tender Thing in its execution and its avoidance of recognisable Shakespearean soundbites. The book is a formal experiment, creating both a prequel to Hamlet and a back story for Ophelia in the tradition of Mary Cowden Clarke's 1912 The Girlhood of Shakespeare's Heroines, using only those words spoken by Ophelia in Hamlet. Creating a corpus of 'Ophelian' from the c.480 words across the 1604 and 1623 texts of the play, Griffiths takes literally the idea of allowing a character to tell their story 'in their own words'. ${ }^{13}$ This means that the narrator is denied even her own name; while a preface (by Claudius) identifies the speaker as Ophelia, Ophelia - who never speaks her own name in Hamlet - refers to herself throughout only as ' $\mathrm{O}$ '. $\mathrm{O}$ recounts the story of her childhood, her relationships with her brother, father and absent mother, and her early friendship with Hamlet, until finally reaching a moment when she chooses whether or not to become part of the narrative of Hamlet or to leave Elsinore. Moving from prose to dramatic dialogue, poetry to song, Griffiths twists Ophelia's words into a variety of shapes.

While the words within this limited corpus recur insistently and musically, Griffiths avoids extended collocations derived from the play, resisting individual moments of overt quotation. Instead, Griffiths plays with frequencies and positioning to make the words in Ophelia's corpus more or less significant as appropriate. To take some significant examples, the word 'Hamlet' appears twice in Ophelia's dialogue (the $101^{\text {st }}$ most spoken word in a corpus of 1,166 words), both times in reference to the character $(1.3 .89,2.1 .76)$; in Griffiths' text, the word appears only once in a corpus of 39,835 words, and describes a small town (44); Hamlet himself is demoted significantly in Griffiths' novel. The word 'choose' only appears once in

\footnotetext{
12 Julie Sanders, Adaptation and Appropriation (London: Routledge, 2006), p. 4.

${ }^{13}$ Griffiths lists 483 'letter strings', of which five pairs duplicate letters with additional punctuation (a/ 'a', ha/ha', I/i', o/o', 't/t') (Paul Griffiths, private communication). This number includes plurals; thus, 'remembrance' and 'remembrances' count as two separate words. Some flexibility is allowed by words such as th' and 's which serve as detachable prefixes and suffixes. I am grateful to Griffiths for his extraordinary generosity in discussing his work.
} 
each text, but restricting it to a single usage in the much longer let me tell you increases its significance; the word is held back to serve as the novel's final word, making the point that the ability to choose is denied to $\mathrm{O}$ until this point. Perhaps more significantly, Ophelia's distinctive verbal tags are muted. The collocation 'my lord' appears no fewer than 27 times in Ophelia's dialogue, leading to these words being the second and fifth most-spoken words by the character. In let me tell you, however, the collocation appears only eight times, with 'my' slipping to sixth and 'lord' being only the $187^{\text {th }}$ most spoken word. The markers of politeness and deference that mark Shakespeare's Ophelia are absent in O's discourse.

A reader looking for verbal echoes of Ophelia is therefore frustrated by the paucity of distinctive lines or phrases from Hamlet. Where these do occur, they are significant - Griffiths himself points to the phrase 'Words, words, words' (2.2.189), spoken as a prophecy of something Hamlet will say in the future - but they are few. ${ }^{14}$ As with A Tender Thing, the process of recognition operates here to equate form with content. While Power's play reorganises whole lines to mimic the unreliable distortions of fragmented memory, Griffiths' strategy evokes the narrative of Hamlet through scenes involving prophecy and foreshadowing, but focuses on the plight of a character who is neither allowed to speak, nor has words appropriate to the task. 'My words may be poor, but they will have to do.'

The effect of Griffiths' use of quotation is to both constrain and liberate O. She is limited by the words she borrows from Shakespeare, and this in turn limits her ability to explain her own experience; she cannot articulate events beyond her own pre-defined vocabulary. Yet as everything spoken or written by other characters is filtered through her corpus as well as their own, $\mathrm{O}$ has a larger word pool than any other character in the book and thus assumes linguistic privilege. When the young Laertes (designated 'Little' here, as Ophelia never names 'Laertes') complains in a letter to his father about $\mathrm{O}$ stealing his mirror, $\mathrm{O}$ has to translate for the reader: "My grace" - I think he meant "glass" - "is my own. Tell O".' (62). O/Ophelia has access to the word 'glass' but Little/Laertes does not, ceding to $\mathrm{O}$ the responsibility and privilege of elucidating meaning. Far from being controlled by others' words, $O$ controls those of others.

Yet while Griffiths in this example makes clear O's linguistic advantage over Little, he goes on to use misquotation to undermine his narrator. In one key scene, O's father writes letters home from court, including advice that he wishes $\mathrm{O}$ to pass on to Little. The letter is composed of words available only in Polonian and Ophelian, limiting the word pool further.

'It may be that I will not see you all for some time, and if so, there is something I would like you to tell him from me, if and when he must go away from home.

This is what I would say:

' "Give your thoughts no tongue.

، "What men you know, and that show you affection, you should keep by you.

، "Give each lord your shoulder, but no madam your heart.

، "Do not take and do not give. You know what this means.

\footnotetext{
${ }^{14}$ Griffiths, let me tell you, p. 36 (and private communication). Ophelia's use of 'in my mind's eye' (p. 89) is another example.
} 
“ "Look good when you go out, but doubt fashion.

' "This most of all: to your own soul be true, and it must come from this, as

night from day, you may not then be false to rich, to poor." (70)

As $\mathrm{O}$ reports this letter (is she reading or retelling?), the restrictions placed on her father's words reconstruct his sententiae in words that are familiar to her. At one level this allows $\mathrm{O}$ to put into plain speech her father's wordy discourse. Yet the familiarity of Polonius' famous advice from Hamlet 1.3 also excludes O. 'You know what this means' goes straight over O's head - the father's address depends on Little understanding his subtext, but $\mathrm{O}$ has no more words with which to expand on what the ambiguous 'Do not take and do not give' may mean; she cannot articulate the commonplace 'Neither a borrower nor a lender be' (Hamlet 1.3.75). The complexity of Polonius' advice to Laertes, in a monologue that ignores Ophelia, is replicated here despite O's linguistic privilege. Even more poignantly, 'to your own soul be true' reveals that $\mathrm{O}$ does not have access to the word 'self', and thus implicitly is devoid of self-determination. Throughout Griffiths' novel $\mathrm{O}$ wields almost no control over her surroundings, which are determined by characters ranging from a Nurse to her father and brother, to the King and the absent, nameless mother who haunts her memories.

The work of recognition and remembrance instigated by quotation practice here draws attention to what is not said. In a later letter from the father to $\mathrm{O}$, one absence becomes very clear:

I was up late at a show. I know you do not like the music I like; still, I think you would like this from what they did:

Love, love me do,

You know I love you,

I'll never be true,

So PLEASE, love me do.

'Well, you have to know the music. It's not at all like the king's: I'll play it for you when home - which is where I long to be!' (71)

Now Lennon and McCartney are transmitted via Polonian and Ophelian, and the fact that Love $M e$ Do can still be reconstructed despite the double restriction occasions humour. Yet the evocation of a lyric perhaps as iconic to Griffiths' audience as any Shakespearean passage makes a serious point, the misquotation signalling to the reader that Ophelia/O never uses the word 'always'. 'Never' is a mistake, an intrusion, the incorrect word in an obvious quotation. The text depends on the reader's assumed knowledge of the Beatles song for what should appear in its place, and 'always' becomes the absent ghost haunting the misquotation. Griffiths' other key work in Ophelian is the spoken sound poem there is still time (2004), and the lack of 'always' in both belies anxiety over Ophelia's ticking clock. For Ophelia, there is no 'always', and her fate appears prescribed by the nature of the prequel. This culminates in the novel's final lines: 
This time I could make things better for him. I know I could. It does not have to go as they say.

I could do that: go home and not go on.

I could go on, and find what I still do not know.

This way, that way.

I have stayed here to think, and then:

I choose. (139)

The possibility of her choice is undermined, however, by the restrictions of her vocabulary. Her choices are limited by what she can articulate, and what she can articulate is only what already belongs to Shakespeare's Ophelia. Coupled with the assumption that a prequel necessarily leads into the action of the original, O's 'choice' may be no choice at all. While Griffiths' novel traces a trajectory leading up to a moment of what $\mathrm{O}$ experiences as genuine choice, the re-emergence of the $u r$-text in the final pages (Barnardo and Francisco's opening lines of Hamlet are heard through a window) puts the freedom of Griffiths and $\mathrm{O}$ in direct tension with the looming inevitability of Hamlet itself. The reader's allegiance to $\mathrm{O}$ may be in her challenge to the established Shakespearean narrative, or it may be sympathy for her apparent inability to alter events.

\section{Intrusive Shakespeare}

Early in A Tender Thing, during the characters' only scene of full health together, Power quotes elements of the balcony scene to capture the couple's playfulness; Romeo's 'O, wilt thou leave me so unsatisfied?' (2.2.125) in this context becomes banter between a husband and wife (12). Here, however, fall the most obvious insertions from outside Romeo and Juliet, as lines of remembrance are interpolated from the sonnets:

JULIET: Let that sun shine and show us as we are. (original)

That time of year thou mayst in us behold,

(Sonnet 73, 1-7)

When yellow leaves, or none, or few do hang

Upon those boughs which shake against the cold,

Bare ruined choirs, where once the sweet birds sang.

In me thou seest the twilight of such day,

As after sunset fadeth in the west,

Which by and by black night doth take away.

ROMEO: To me, fair friend, you never can be old,

(Sonnet 104, 1-3)

For as you were when first your eye I eyed,

Such seems your beauty still.

JULIET: And how is that?

(original) 
ROMEO: Such as would make a man sing like a bird!

Our love was new, and then but in the spring,

When I was wont to greet it with my lays.

Dost thou remember how I used to sing?

\section{(original)}

(Sonnet 102, 5-6)

(original) (13)

The importation of Shakespeare from outside the play's source corpus distinguishes this moment, and the creation of iambic pentameter lines by Power to join them serves the function of an additional set of Kidnie's 'invisible quotation marks', demarcating these lines from the surrounding text (drawn from Romeo) so that, in de Grazia's words, they 'enclose rather than highlight passages, drawing attention to words that are imported from elsewhere'. ${ }^{15}$ This is a more traditional use of citation within the play's broader quoting structure, and implies the insufficiency of Romeo and Juliet for Power's purpose at this point. Even though Power's overall project is one of playful pastiche and reconstruction of a 'Shakespearean' tone, his importation of external quotation at this point suggests that a deferential evocation of Shakespeare remains part of the play's premise.

In a similar way, foreign Shakespeare is introduced into let me tell you chapter 11, although here adhering to the book's rules. In this chapter, Little receives four love letters containing sonnets. The first lines of each may be familiar:

What's mine is yours and what is yours is mine (Measure for Measure, 5.1.529)

I cannot tell what you and other men (Julius Caesar, 1.2.93)

It is not night when I do see your face (A Midsummer Night's Dream, 2.1.221)

They do not love that do not show their love. (The Two Gentlemen of Verona, 1.2.31)

(116-20)

Griffiths' ability to find genuine Shakespearean quotations while still using only Ophelia's words is an unremarked 'Easter Egg' for attentive readers, and his creation of sonnets themselves a form that highlight creativity under constraint - demonstrate his ingenuity. Nonetheless, these quotations also create an extruding presence, the sonnets (from an unnamed sender) declaring what appears to be a Shakespearean origin. Griffiths quotes Shakespeare's Ophelia quoting Shakespeare, and in so doing the elsewhere distorted Shakespearean voice reassumes a momentary prominence.

Both A Tender Thing and let me tell you are new works, but remain ghosted by Shakespeare. The relationship between Shakespeare and these texts poses interesting

\footnotetext{
${ }^{15}$ De Grazia, 'Quotation Marks', p. 60.
} 
difficulties for an analysis of practices of quotation. The restrictions that both texts advertise imply deference, yet both authors resist slavish adherence to their originals, instead creating intertextual palimpsests that playfully insist on the present text's multiplicity while dispersing the Shakespearean voice on which they are premised. By employing quotation within quotation, as in the sonnets above, both texts foreground the careful utilisation of words as their key theme, as in the quotation from Griffiths with which I opened this chapter. That passage makes clear that one of O's denied words is 'power'; she has to assert, awkwardly, 'I have the powers' (my emphasis). Her restriction is manifest even at the initial moment of celebrated liberation. By working within Shakespeare, both authors cede power in a strategy that I see as political; the restrictions on their own expression map onto the voices of Ophelia and Juliet that struggle for expression in Shakespeare. By turning Ophelia, Juliet and their plays into palimpsests of reorganised quotation, and by creatively exploiting their linguistic dependence on Shakespeare, Power and Griffiths draw attention to the silences in their sources, to the issues of restricted expression and mute suffering that do not themselves provide soundbites for quotation. These constrained words may be poor, but they will (have to) do. 